УДК 621.317.619

DOI: https://doi.org/10.36910/6775-2313-5352-2019-14-24

Тичков Д.В., Бондаренко М.О., д.т.н., доцент

Черкаський державний технологічний університет

Антонюк В.С., д.т.н., професор,

Національний технічний університет України

«Київський політехнічний інститут імені Ігоря Сікорського»

\title{
ОСОБЛИВОСТІ РОЗРАХУНКУ ТА ДОСЛІДЖЕННЯ ЄМНІСНИХ ПЕРЕТВОРЮВАЧІВ ДІЕЛЕКТРИЧНОЇ ПРОНИКЛИВОСТІ 3 РІЗНОЮ ФОРМОЮ ЕЛЕКТРОДІВ
}

В ході проведених розрахунків та аналізу експериментальних даних встановлена можливість проектування ємнісних перетворювачів з обкладками складної конфігурачії (квадратних, прямокутних та круглих) за умови, щзо одна з обкладок залишається нерухомою, тоді, як інша - рухається в паралельній площині відносно нерухомої. Проведені експериментальні дослідження підтверджують закономірності зміни ємності перетворювача від величини діелектричної проникливості середовища та геометричних параметрів обкладок цього перетворювача. Показано, щзо: для квадратної форми обкладок, при рівномірному збільшенні площі їх перекриття, ємність перетворювача збільшується за параболічним законом; для прямокутної форми обкладок, при рівномірному збільшенні кута перекриття обкладок, ємність перетворювача збільшується тангенціально; для комбінованої (рухомої прямокутної та нерухомої круглої) форми обкладок, при рівномірному їх русі, ємність перетворювача збільшується за гіперболічним законом. Завдяки високій точності результатів експериментальних досліджень діелектричної проникливості матеріалів, відкриваються можливості подальших досліджень однорідності даних матеріалів та можливості виявлення внутрішніх дефектів, які можуть з'явитися в процесі виготовлення виробів при порушенні технології виробництва.

Ключові слова: ємнісний перетворювач, діелектрична проникливість, площа перекриття, електропровідна обкладка, кут перекриття.

Постановка проблеми. Сучасні композиційні матеріали мають унікальний набір електричних характеристик, що залежать від їх діелектричних властивостей. При цьому, такі характеристики можуть змінюватися по перетину матеріалу, як лінійно і нелінійно, так i дискретно. Точні вимірювання цих властивостей повинні забезпечити вчених та інженерів цінною інформацією про доцільність використання цього матеріалу в різних конструкціях контрольно-вимірювальних приладів та систем на їх базі, що знайшло застосування в різноманітних галузях сучасної авіакосмічної техніки, мікро- та наноелектроніки, функціональної медицини, тощо. Це, в свою чергу, дозволяе підвищити точність та надійність таких приладів, та, в цілому, поліпшити процес контролю, що відбувається за їх допомогою.

Так, вимірювання діелектричних властивостей матеріалів може дати інформацію про параметри, які є критичними при проектуванні в багатьох областях електроніки. Наприклад, втрати в ізоляції кабелю, імпеданс підкладки або частота діелектричного резонатора залежать від їх діелектричних властивостей. Знання діелектричних властивостей матеріалів також дає переваги в більш сучасних галузях з областей промислової мікрохвильової обробки продуктів харчування, гуми, пластику та кераміки.

Відомими вітчизняними та закордонними фахівцями в області вимірювання електричних та неелектричних величин, у тому числі й електроємнісним способом, такими, як: Шарапов В.М., Готра 3.Ю., Поліщук Є.С., Івах Р.Г., Евтіхієв М.М., Базіло К.В., Zhu Y., Samani A., Risos A. та іншими проводяться вивчення і аналіз існуючих ємнісних перетворювачів та методів на яких базуються принципи їх дії. Проте, такі дослідження проводяться цими авторами для ємнісних перетворювачів класичних конструкцій та прямокутної форми обкладок, що розташовані нерухомо одна відносно. Інформацію щодо вимірювання діелектричної проникливості ємнісними перетворювачами з обкладками складної форми, за умови, що одна з таких обкладок закріплена нерухомо, а інша - рухома відносно першої в паралельній до неї площині у відкритих літературних джерелах та джерелах Інтернет не знайдено [1-10]. 
Тому, актуальні на сьогоднішній день питання визначення діелектричної проникливості ємнісними перетворювачами 3 обкладками складної конструкції, коли одна 3 таких обкладок рухається в паралельній площині до іншої - розташованої нерухомо [11-13], досі залишаються невизначеними.

Формулювання цілей статті. Метою дослідження є встановлення закономірностей зміни ємності перетворювача від величини діелектричної проникливості середовища та геометричних параметрів обкладок цього перетворювача.

Методика та основні результати дослідження.

Розрахунок та дослідження ємнісних перетворювачів з обкладками квадратної форми проводилися згідно схеми для вимірювання ємності.

Схема ємнісного перетворювача 3 обкладками квадратної форми, представлена на рис.1.a.

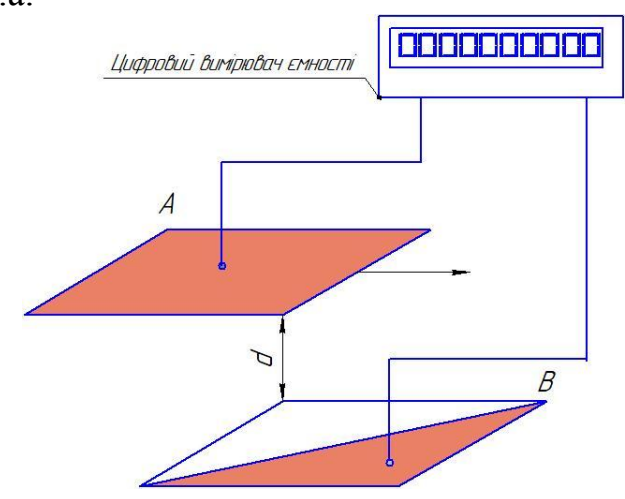

a.

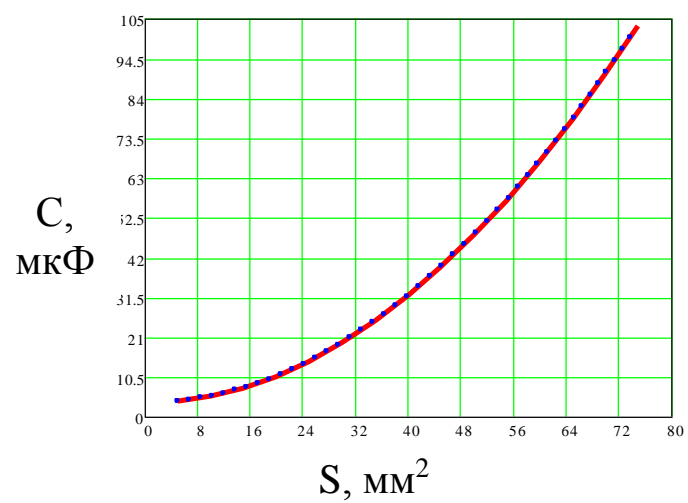

б.

Рис.1. Схема для вимірювання ємності (а) та залежність ємності первинного перетворювача $з$ обкладками квадратної форм від площі перекриття обкладок (б): $\varepsilon=8 ; d=1$ мм,

$A$, $B$ - відповідно, обкладка ємнісного перетворювача, щэо рухається (A) та залишається нерухомою (B); $d$ - відстань між обкладками, ми (товщина діелектричного шару матеріалу)

Для розрахунку такого ємнісного перетворювача використовується розроблена в роботі [1] методика.

При цьому ємність первинного перетворювача 3 обкладками квадратної форми, яка змінюється перекриттям рухомої пластини $A$ іншою - нерухомою пластиною $B$, знаходиться за відомою формулою [4]:

$$
C=\left(\frac{\varepsilon \cdot \varepsilon_{0} \cdot S^{2}}{d}\right)
$$

де $\quad \varepsilon_{0}-$ діелектрична стала, яка дорівнює, $8,85 \times 10^{-12} \mathrm{~A} \cdot \mathrm{c} /(\mathrm{B} \cdot \mathrm{M})$;

$\varepsilon$ - діелектрична проникність матеріалу, що знаходиться у міжелектродному просторі;

$S$ - площа перекриття одної обкладки іншою;

$d$ - відстань між обкладками.

Експериментальне визначення коефіцієнтів функції перетворення $C=f(S)$ та похибки вимірювання проводиться в такій послідовності:

1. За допомогою цифрового вимірювача ємності визначається похибка вимірювання ємності зовнішніх факторів $\Delta C$ (конструктивна складова ємності перетворювача - у нашому випадку $\left.\Delta C=3,5 \times 10^{-12} \Phi\right)$. ємності.

2. Підключаються досліджувані обкладки електродами до цифрового вимірювача

3. Починається переміщення обкладки $A$ відносно обкладки $B$ (рис.1.a) із заданою постійною швидкістю. 3 отриманими результатами вимірювання проводяться необхідні розрахунки за формулою (1), що аналізуються.

В результаті аналізу залежностей (рис.1.б) встановлено, що зі збільшенням площі перекриття обкладок ємність перетворювача збільшується нелінійно (за параболічним законом), що підтверджує адекватність проведених експериментів та розрахунків (розбіжність між розрахунками та експериментами даними не перевищує 1,5\%). 
Розрахунок та дослідження ємнісних перетворювачів з обкладинками прямокутної форми проводилися згідно схеми для вимірювання ємності.

Схема ємнісного перетворювача з обкладинками прямокутної форми представлена на рис.2.а. Експериментальне визначення коефіцієнтів функції перетворення $C=f(S)$ та похибки вимірювання проводиться у послідовності наведеній вище, як для обкладок квадратної форми.

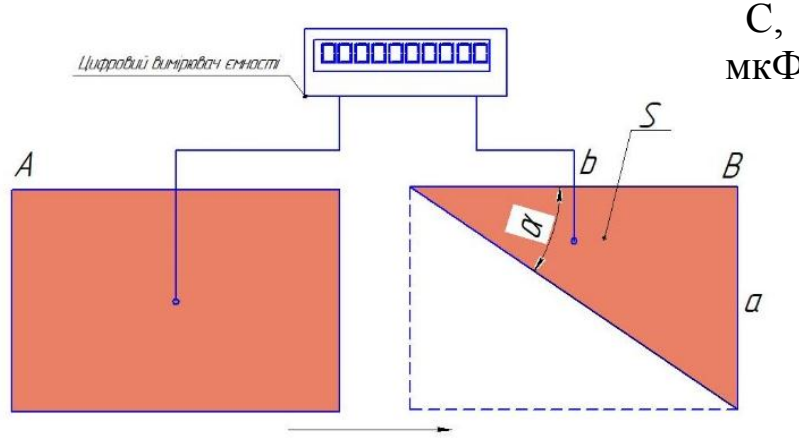

a.

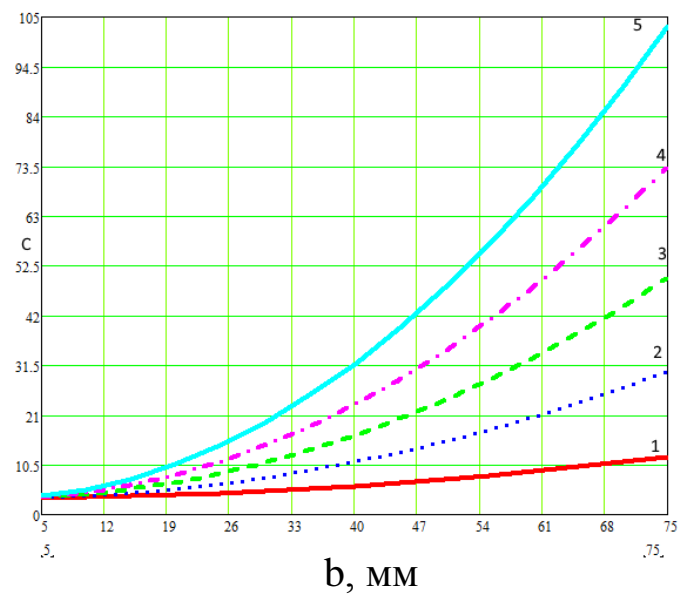

б.

Рис.2. Схема ємнісного перетворювача з обкладками прямокутної форми (а) та графік залежності ємності первинного перетворювача від довжсини обкладки В (b) та кута перекриття $\left(1-\alpha=5^{\circ}, 2-\alpha=15^{\circ}, 3-\alpha=25^{\circ}, 4-\alpha=35^{\circ}, 5-\alpha=45^{\circ}\right)$ (б).

$A, B$ - відповідно, обкладка ємнісного перетворювача, щзо рухається (A) та залишається нерухомою (B); $a$ - ширина обкладок ємнісного перетворювача, ми $(a=b \times \operatorname{tg} \alpha)$.

При цьому, ємність первинного перетворювача 3 обкладками прямокутної форми, площа перекриття обкладок якої змінюється визначається так:

$$
C=\frac{\varepsilon \cdot \varepsilon_{0}}{4 d} b^{4} \cdot \operatorname{tg}^{2}(\alpha),
$$

де

$\varepsilon_{0}$ - діелектрична стала, яка дорівнює, $8,85 \times 10^{-12} \mathrm{~A} \cdot \mathrm{c} /(\mathrm{B} \cdot \mathrm{M})$;

$\varepsilon$ - діелектрична проникність матеріалу, що знаходиться у міжелектродному просторі;

$S$ - площа перекриття одної обкладки іншою, мм² :

$$
S=\frac{1}{2}\left(b^{2} \cdot \operatorname{tg} g(\alpha)\right),
$$

$d$ - відстань між обкладками, мм.

$\alpha-$ відношення сторін електроду на обкладці $B$;

$b$ - довжина перекриття нерухомої обкладки $B$ (рис.2.б) по горизонталі рухомою обкладкою $A$ (5 мм; 10 мм; 15 мм; ...; 75 мм).

В результаті аналізу графіку (рис.2.б) встановлено, що при збільшення кута перекриття $\alpha$ та площі перекриття $S$, ємність перетворювача збільшується за нелінійним законом. При цьому зі збільшенням кута $\alpha$, ємність перетворювача збільшується тангенціально (розбіжність між розрахунками та експериментами даними становила $1,8-3,1 \%$ ).

Розрахунок та дослідження ємнісного перетворювача з нерухомою обкладкою круглої форми та рухомою обкладкою прямокутної форми проводилися згідно схеми для вимірювання ємності.

Схема ємнісного перетворювача з нерухомою обкладкою круглої форми та рухомою обкладкою прямокутної форми, представлена на рис.3.а. Експериментальне визначення коефіцієнтів функції перетворення $C=f(S)$ та похибки вимірювання проводиться у послідовності наведеній вище, як для обкладок квадратної форми. 


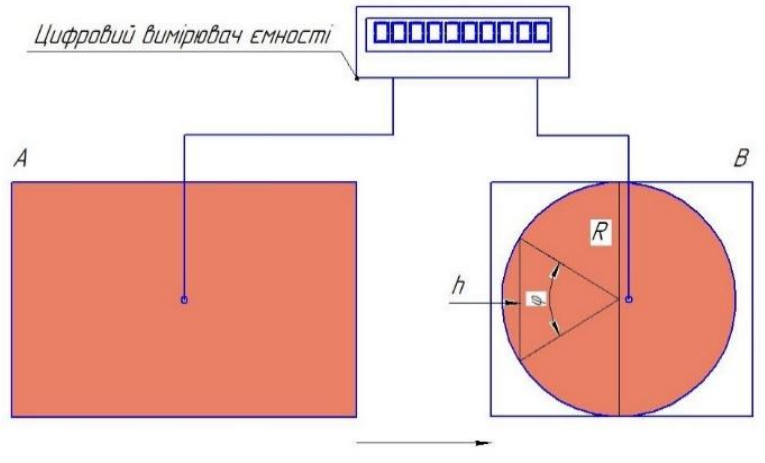

a.

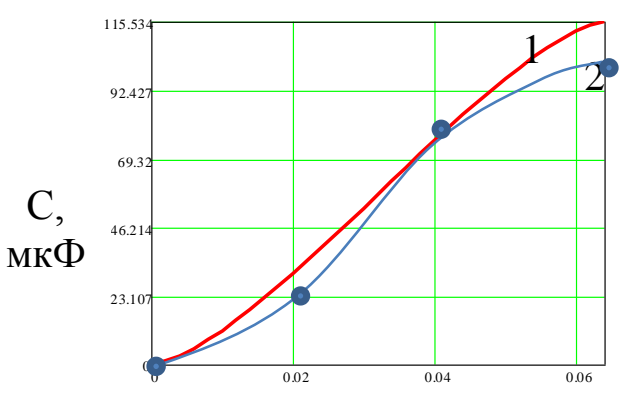

S, $\mathrm{MM}^{2}$

6.

Рис.3. Схема ємнісного перетворювача з нерухомою обкладкою круглої форми (В) та рухомою обкладкою (А) прямокутної форми (а) та залежність ємності С первинного перетворювача від площі перекриття $S$ (б): 1 - розрахункові; 2 - експериментально отримані дані

A, $B$ - відповідно, обкладка ємнісного перетворювача, щзо рухається (А) та залишається нерухомою (B); $\varphi$ - кут перекриття обкладок; $R$ - радіус обкладки круглої форми, мм; $h$ - довжина хорди сектора, що перекривається рухомою обкладкою, мм.

В цьому випадку, ємність первинного перетворювача, яка змінюється перекриттям однією пластиною іншою, визначається так:

$$
C=\frac{\varepsilon \varepsilon_{0} R^{4}}{4 d} \cdot\left(\arcsin \frac{h}{2 R}-\sqrt{h}+\sqrt{\frac{h^{3}}{4 R^{4}}}\right)^{2},
$$

де

$\varepsilon_{0}$ - діелектрична стала, яка дорівнює, $8,85 \times 10^{-12} \mathrm{~A} \cdot \mathrm{c} /(\mathrm{B} \cdot \mathrm{M})$;

$\varepsilon$ - діелектрична проникність матеріалу, що знаходиться у міжелектродному просторі;

$d$ - відстань між обкладками, мм.

$S$ - площа перекриття нерухомої обкладки рухомою, мм²:

$$
S=\frac{R^{2}}{2} \cdot(\varphi-\sin \varphi)=\frac{R^{2}}{2} \cdot\left(\arcsin \frac{h}{2 R}-\sqrt{h}+\sqrt{\frac{h^{3}}{4 R^{4}}}\right),
$$

$\varphi$ - кут перекриття обкладок;

$R$ - радіус обкладки круглої форми, мм;

$h$ - довжина хорди сектора, що перекривається рухомою обкладкою, мм.

Залежність зміни ємності розробленого перетворювача від площі перекриття обкладок представлена на рис.3.б. За результатами аналізу цієї залежності встановлено, що у даній експериментальній схемі на початковому та завершальному етапах перекриття обкладок зміна ємності відбувається нелінійно, тоді, як в центральній частині, ця залежність носить майже лінійний характер. На думку авторів, це повзано з більш різкою зміною площі перекриття саме в першій та останній чвертях діаметру площі круглої обкладки. Слід також зауважити, що й розбіжність між експериментальними та розрахунковими даними вища, ніж у попередніх випадках у $2,6-5,2$ рази і становить $7,8-8,1 \%$.

Висновки. В результаті дослідження ємнісних перетворювачів 3 динамічними та статичними обкладками різної геометричної форми для вимірювання діелектричної проникливості різних матеріалів були запропоновані розрахункові схеми, адекватність яких підтверджена експериментально. Розбіжність між експериментальними та розрахунковими даними при цьому становила: для квадратної форми обкладок - не більше 1,5\%; для прямокутної форми обкладок - 1,8 - 3,1\%; для комбінованої (рухомої прямокутної та нерухомої круглої) форми обкладок $-7,8-8,1 \%$.

Встановлено, що у випадку двох квадратних або прямокутних електродів з різними площами перекриття, графік залежності має нелінійний параболічний характер, в той час, як для одного прямокутного та круглого електроду, цей графік залежності носить нелінійний гіперболічний характер, що може бути вигідно використано при розробці та впровадженні в даних ємнісних перетворювачів в різноманітних приладах та системах, в тому числі мікро 
системної техніки при нанесенні на нерівні поверхні (на приклад ємнісних датчиках обертового типу) тощо.

Подальші дослідження авторів у цьому напрямку будуть присвяченні розрахункам та розробці ємнісних перетворювачів складної геометричної форми обкладок, що рухаються незалежно для визначення діелектричної проникливості різноманітних матеріалів.

\section{Інформаційні джерела}

1. Шарапов, В. М.; Минаев, И. Г.; Базило К. В.; и др., Емкостные датчики / Под. ред. В.М.Шарапова, Черкассы : Брама-Украина, 2010, 152 с.

2. Zhu, Y.; Moheimani, S. O. R.; Yuce, M. R.; et al. Simultaneous Capacitive and Electrothermal Position Sensing in a Micromachined Nanopositioner. IEEE Electron Device Letters. 2011, Vol.32, Iss.8, P. 1146-1148. DOI: 10.1109/LED.2011.2155027

3. Івах, Р. М. Методика розрахунку циліндричного ємнісного первинного перетворювача із внутрішнім електродом складної конструкції // Вимірювальна техніка і метрологія, C. $125-131$.

2006 ,

4. Готра, 3. Ю.; Ильницкий, Л. Я.; Полищук, Е. С.; и др., Датчики: Справочник / Под ред. 3.Ю. Готры, О.И. Чайковского, Львов : Каменяр, 1995, 312 с.

5. Джежора, А. А. Влияние экрана подложки на емкость датчика / А. А. Джежора, В. В. Рубаник // Современные методы и приборы контроля качества и диагностики состояния объектов: материалы III междунар. научно-технич. конф. - Могилев, 2009. - С.110-112.

6. Hesabgar S. M.; Jafari R.; Samani A.; et al. Accurate Technique for Measuring Electrical Permittivity of Biological Tissues at Low Frequencies and Sensitivity Analysis. IEEE International Symposium on Medical Measurements and Applications (MeMeA) (11-13 June 2018, Rome, Italy) DOI: 10.1109/MeMeA.2018.8438680.

7. Risos, A.; Long, N.; Hunze, A.; Gouws, G. A 3D Faraday Shield for Interdigitated Dielectrometry Sensors and Its Effect on Capacitance. Sensors. 2017, Vol.17, 77; DOI: 10.3390/S17010077.

8. Risos, A.; Gouws, G. A In-situ aging monitoring of transformer oil via the relative permittivity and DC conductivity using novel interdigitated dielectrometry sensors (IDS). Sensors and Actuators B: Chemical 2019, Vol.287, P. 602-610; DOI: 10.1016/j.snb.2018.12.037.

9. Емкостные преобразователи, чувствительные элементы, датчики [Електронний pecypc]. - 2015. - Режим доступу до ресурсу: https://sensorse.com/page139.html.

10. Capacitive Sensors [Електронний ресурс]. - 2000. - Режим доступу до ресурсу: http://www.capsense.com/capsense-wp.pdf

11. Tychkov D. V. Measurement methods analysis of dielectric permeability / D. V. Tychkov, C. V. Bazilo, V. V. Tychkov [Text] // Датчики, прилади та системи-2018 : VII Міжнародна науково-технічна конференція, Черкаси - Херсон - Лазурне, 17-21 вересня 2018 р. : тези доповідей. - Черкаси: видавець ФОП Гордієнко Є.І., 2018. - С. 38-39.

12. Тичков Д. В. Смнісні перетворювачі як датчики контролю електродинамічних параметрів діелектричних матеріалів у виробничих процесах електронного приладобудування [Електронний ресурс] / Д. В. Тичков, К. В. Базіло, В. В. Тичков // Метрологічні аспекти прийняття рішень в умовах роботи на техногенно-небезпечних об'єктах : Всеукраїнська науково-практична інтернет-конференція здобувачів вищої освіти і молодих учених, Харків, 12 листопада 2018 р. : матеріали конференції. - Харків : ХНАДУ, 2018. - С. 120-122.

13. Tychkov D. V. Capacitive method of dielectric permeability measurement of substances [Text] / D. V. Tychkov, C. V. Bazilo, V. V. Tychkov // Проблеми інформатизації : Шоста Міжнародна науково-технічна конференція, Черкаси, 14-16 листопада 2018 р. : тези доповідей. - Черкаси : ЧДТУ, ВА ЗС АР, УЕІГН, ПНТУ, 2018. - 125 с.

\section{Тычков Д.В., Бондаренко М.А., д.т.н., доцент}

Черкасский государственный технологический університет

Антонюк В.С., д.т.н., профессор,

Национальный технический университет Украины «Киевский политехнический институт имени Игоря Сикорского» 


\title{
ОСОБЕННОСТИ РАСЧЕТА И ИССЛЕДОВАНИЯ ЕМКОСТНЫХ ПРЕОБРАЗОВАТЕЛЕЙ ДИЭЛЕКТРИЧЕСКОЙ ПРОНИЦАЕМОСТИ С РАЗЛИЧНЫМИ ФОРМАМИ ЭЛЕКТРОДОВ
}

В ходе проведенных расчетов и анализа экспериментальных данных установлена возможность проектирования емкостных преобразователей $c$ обкладками сложной конфигурации (квадратных, прямоугольных и кругльх) при условии, что одна из обкладок остается неподвижной, тогда как другая - движется в параллельной плоскости относительно неподвижной. Проведенные экспериментальные исследования подтверждают закономерности изменения емкости преобразователя от величины диэлектрической проницаемости среды и геометрических параметров обкладок этого преобразователя. Показано, что: для квадратной формы обкладок, при равномерном увеличении площади их перекрытия, емкость преобразователя увеличивается за параболическим законом; для прямоугольной формы обкладок, при равномерном увеличении угла перекрытия обкладок, емкость преобразователя увеличивается тангенциально; для комбинированной (подвижной прямоугольной и неподвижной круглой) формь обкладок, при равномерном их движении, емкость преобразователя увеличивается за гиперболическим законом. Благодаря высокой точности результатов экспериментальных исследований диэлектрической проницаемости материалов, открываются возможности дальнейших исследований однородности данных материалов и возможности выявления внутренних дефектов, которые могут появиться в процессе изготовления изделий при нарушении технологии производства.

Ключевые слова: емкостный преобразователь, диэлектрическая проницаемость, площадь перекрытия, электропроводящая обкладка, угол перекрытия.

\section{Tychkov D.V., Bondarenko M.A., Doctor of Technical Sciences, Associate Professor}

Cherkasy State Technological University

\author{
Antonjuk V.S., Doctor of Technical Sciences, Doctor o fTechnical Sciences, AssociateProfessor \\ Professor \\ National Technical University of Ukraine "Igor Sikorsky Kyiv Polytechnic Institute"
}

\section{FEATURES OF CALCULATION AND RESEARCHES BY CAPACITY SENSORS DIELECTRIC PERMITTIVITY WITH DIFFERENT ELECTRODE FORMS}

In the course of the calculations and analysis of experimental data, the possibility of designing capacitive sensors with plates of complex configuration (square, rectangular and round) was established, provided that one of the plates remains stationary, while the other is moving in a parallel plane relative to the stationary. The experimental researches confirmed the patterns of capacitance change of the sensor from the magnitude of the dielectric insight of the medium and the geometric parameters of the plates of this sensor. It is shown that: for a square shape of the cover, with a uniform increase in the area of their overlap, the capacitance of the sensor increases according to the parabolic law; for a rectangular form of the cover, with a uniform increase in the angle of the overlap of the plates, the capacitance of the sensor increases tangentially; for combined (moving rectangular and fixed circular) shapes of the plates, with their uniform motion, the capacitance of the sensor increases with hyperbolic law. Due to the high accuracy of the results of experimental studies of dielectric insight of materials, opportunities for further research on the homogeneity of these materials and the possibility of identifying internal defects that may appear in the process of manufacturing products in violation of production technology.

Keywords: capacitive sensor, dielectric constant, overlap area, electrically conductive plate, overlap angle. 